\title{
Pertumbuhan Tanaman Kelapa (Cocos nucifera L.) dengan Pemberian Air Kelapa
}

\author{
The Growth of Coconut Plant (Cocos nucifera L) During The Provision of Coconut \\ Water
}

\author{
Mira Ariyanti ${ }^{1}$, Cucu Suherman ${ }^{1}$, Yudithia Maxiselly ${ }^{1}$, Santi Rosniawaty ${ }^{1}$ \\ ${ }^{1}$ Departemen Budidaya Pertanian, Fakultas Pertanian, Universitas Padjadjaran. Jl. Raya \\ Bandung-Sumedang km.21, Jatinangor, Jawa Barat, Indonesia \\ email : mira.ariyanti@unpad.ac.id

\begin{tabular}{|l|l|}
\hline Diterima: 13 Maret 2018 & Disetujui: 22 April 2018 \\
\hline
\end{tabular}

\begin{abstract}
Abstrak
Di Indonesia sebagian besar perkebunan kelapa merupakan perkebunan rakyat dimana teknik budidaya yang diterapkan belum diperhatikan dengan baik yang menyebabkan produktivitasnya rendah. Penggunaan input misalnya air kelapa sebagai ZPT alami diharapkan dapat menjadi teknologi yang bermanfaat dalam mengembangkan salah satu aspek teknik budidaya dalam pengelolaan tanaman kelapa. Air kelapa mengandung banyak bahan mineral dan hormon sitokinin dan auksin yang dapat membantu meningkatkan pertumbuhan tanaman. Percobaan ini bertujuan untuk mengetahui pengaruh pemberian air kelapa muda terhadap pertumbuhan tanaman kelapa belum menghasilkan (TBM). Percobaan dilakukan di Kebun Percobaan Ciparanje Fakultas Pertanian Universitas Padjadjaran, Jatinangor Kabupaten Sumedang pada bulan Maret 2017 - Mei 2017. Penelitian ini menggunakan Rancangan Acak Kelompok (RAK) dengan perlakuan air kelapa yang terdiri dari tiga taraf konsentrasi yaitu $\mathrm{A}=100 \%$ air kelapa, $\mathrm{B}$ $=50 \%$ air kelapa $+50 \%$ air, $\mathrm{C}=100 \%$ air yang masing-masing diulang enam kali. Uji lanjut menggunakan uji lanjut Beda Nyata Terkecil (BNT) taraf 5\%. Hasil penelitian menunjukkan bahwa pemberian air kelapa dengan konsentrasi $100 \%$ menghasilkan respons terbaik pada pertumbuhan luas daun kelapa pada fase TBM. Air kelapa dengan konsentrasi 50\% cenderung menghasilkan peningkatan pertumbuhan tinggi kelapa TBM.
\end{abstract}

Kata kunci : kelapa, pertumbuhan, air kelapa

\begin{abstract}
In Indonesia, most of the coconut plantations are smallholder plantations where the cultivation techniques that have been applied have not been properly considered which have caused low productivity. The use of inputs such as coconut water as natural PGR is expected to be a useful technology in developing one aspect of cultivation techniques in the management of coconut plants. Coconut water contains many minerals and cytokinin and auxin hormones which can help increase plant growth. This experiment aims to determine the effect of giving young coconut water to the growth of immature coconut plant. The experiment was conducted at Ciparanje Experimental Garden of Agriculture Faculty of Padjadjaran University, Jatinangor, Sumedang Regency. This study used Randomized Block Design with different coconut water treatments concentration consisting of three levels were $\mathrm{A}=100 \%$ coconut water, $\mathrm{B}=50 \%$ coconut water $+50 \%$ water, $\mathrm{C}=100 \%$ water with six replications. The further test uses Least Significance Different (LSD) at the level of 5\%. The results showed that giving coconut water with a concentration of $100 \%$ produced the best response to the growth of coconut leaf area during the immature phase. Coconut water with a concentration of $50 \%$ tends to produce an increase in the growth of plant height.
\end{abstract}

Keywords : Coconut, Growth, Coconut Water 


\section{PENDAHULUAN}

Tanaman kelapa (Cocos nucifera L.) merupakan tanaman yang memiliki posisi strategis terutama sebagai bahan baku pembuatan minyak goreng. Kelapa merupakan tanaman tropis yang telah lama dikenal masyarakat Indonesia, hal ini terlihat dari penyebarannya hampir di seluruh wilayah Nusantara (Dirjenbun, 2012). Pada tahun 2010 luas areal tanaman kelapa tercatat 3739.35 ribu ha, didominasi oleh perkebunan rakyat seluas 3697.03 ribu ha $(98.87 \%)$, perkebunan besar negara seluas 4.29 ribu ha $(0.11 \%)$ dan perkebunan besar swasta seluas 38.02 ribu ha (1.02\%),

Selama ini komoditas kelapa hanya dimanfaatkan produk primernya saja, baik dalam bentuk kelapa segar maupun kopra untuk bahan baku minyak goreng. Pengembangan dan pemanfaatan produk hilir kelapa belum banyak dilakukan, demikian pula pemanfataan hasil samping

Salah satu hasil samping dari buah kelapa adalah air kelapa. Air kelapa banyak mengandung mineral antara lain $\mathrm{Na}, \mathrm{Ca}$, $\mathrm{Mg}, \mathrm{Fe}, \mathrm{Cu}, \mathrm{P}$ dan. Air kelapa selain mengandung mineral juga mengandung hormon auksin dan sitokinin. Kedua hormon ini penting dalam pertumbuhan dan jumlah daun pada tanaman. Air kelapa mengandung fitohormon sitokinin, auksin, dan giberelin. Kandungan-kandungan Peningkatan pertumbuhan vegetatif pada TBM dapat dilakukan dengan aplikasi dengan total produksi sebesar 3166.6 ribu ton setara kopra, yaitu perkebunan rakyat sebesar 3.126 ribu ton $(98.73 \%)$, perkebunan besar negara sebesar 1.8 ribu ton $(0.06 \%)$ dan perkebunan besar swasta sebesar 38,47 ribu ton (1.22\%) (Dirjenbun, 2012). Tanaman kelapa merupakan tanaman sosial karena lebih 98\% diusahakan oleh petani sehingga perkebunan kelapa banyak didominasi perkebunan rakyat dibandingkan perkebunan negara ataupun swasta (Dewan Kelapa Indonesia, 2014).

dan limbah. Upaya pengembangan produk dan pemanfaatan hasil samping dan limbah akan meningkatkan nilai tambah produk kelapa yang pada gilirannya akan dapat meningkatkan pendapatan petani kelapa (Dirjenbun, 2012).

hormon tersebut berperan dalam memicu terjadinya pembelahan sel, pemanjangan sel dan diferensiasi jaringan terutama dalam pertumbuhan tunas pucuk (Saptaji, 2015). Air kelapa juga mengandung unsur kalium, mineral, magnesium, ferum, cuprum, dan sulfur yang berfungsi untuk menambah nutrisi dalam pertumbuhan tanaman (Tiwery, 2014).

ZPT. Zat pengatur tumbuh berfungsi untuk menginisiasi pembelahan, pemanjangan dan 
pembesaran sel yang dapat menunjang peningkatan pertumbuhan vegetatif tanaman. Pelaksanaan penggunaan ZPT oleh petani masih terkendala oleh harga ZPT yang mahal dan kurangnya pengetahuan tentang penggunaan ZPT tersebut, oleh sebab itu perlu dilakukan penggunaan bahan alternatif yang alami seperti air kelapa. Air kelapa merupakan salah satu ZPT yang efisien karena kelapa memiliki volume air yang relatif banyak,

Penggunaan air kelapa sebagai salah satu faktor input teknik budidaya dalam pemanfaatannya sebagai ZPT alami dapat dilakukan untuk meningkatkan pertumbuhan kelapa. Sejauh ini pemanfaatan air kelapa masih sangat terbatas meskipun diketahui air kelapa mengandung banyak unsur yang bermanfaat bagi tanaman. Adapun air kelapa yang dapat digunakan sebagai ZPT adalah kelapa muda. Air kelapa memiliki sifat asam terutama meningkat pada air kelapa tua (Torar dan Daniel, 2010). Dalam penelitian yang dilakukan oleh Fodhil (2014) dinyatakan bahwa pemberian air kelapa dengan konsentrasi 50\% Penelitian ini bertujuan untuk mengetahui konsentrasi air kelapa yang meghasilkan respons terbaik pada

\section{METODE PENELITIAN}

Percobaan dilakukan di Kebun Percobaan Ciparanje Fakultas Pertanian, Universitas Padjadjaran dengan ketinggian mudah didapat, dan memiliki harga yang relatif murah (Yong et al., 2009). Kandungan zat yang ada dalam air kelapa dapat dimanfaatkan untuk pertumbuhan tanaman kelapa kopyor. Konsentrasi sitokinin yaitu $0,0089 \%$ lebih tinggi dibandingkan auksin yaitu 0,0039\% dalam air kelapa muda ini menyebabkan terjadinya diferensiasi dan pembentukan tunas (Rosniawaty dkk., 2018).

berpengaruh terbaik terhadap pertambahan jumlah akar, volume akar, panjang akar, bobot segar buah naga dan bobot kering buah naga. Penelitian lain yang dilakukan oleh Renvillia et al. (2016), pemberian air kelapa pada konsentrasi $50-100 \%$ terbukti dapat meningkatkan keefektifan atau pertumbuhan stek batang jati. Pertumbuhan tanaman dapat terangsang apabila ZPT diberikan dalam konsentrasi rendah (Fahmi, 2016). Konsentrasi merupakan banyaknya zat yang terlarut dalam satu liter air (Panut, 2008). Konsentrasi suatu zat akan mempengaruh kinerja zat tersebut, sehingga pemberian konsentrasi perlu dilakukan secara tepat.

pertumbuhan tanaman kelapa fase TBM (tanaman belum menghasilkan).

tempat $\pm 750 \mathrm{~m}$ dari permukaan laut, ordo tanah Inseptisol, tipe curah hujan $\mathrm{C}$ menurut klasifikasi Schmidt dan Fergusson. 
Waktu percobaan Maret 2017- Mei 2017. Bahan yang digunakan adalah tanaman kelapa umur 1,5 tahun, air kelapa, pupuk NPK (diberikan sebagai pupuk dasar). Metode yang digunakan berupa metode eksperimen dengan rancangan acak Alat dan Bahan

Bahan yang digunakan adalah tanaman kelapa berumur 1.5 tahun, air kelapa, pupuk NPK Mutiara. Peralatan yang Pelaksanaan Percobaan

Persiapan percobaan meliputi pemberian pupuk majemuk NPK mutiara dan pembumbunan tanah di sekitar tanaman kelapa. Pemberian perlakuan dilakukan pada minggu selanjutnya dengan cara menyiramkan larutan ke permukaan tanah di sekitar perakaran tanaman kelapa. Pengamatan dilakukan setiap minggu, dimulai dari 0 MSP (sebelum perlakuan diberikan) sampai dengan 12 MSP (minggu

\subsection{Pengamatan}

\subsubsection{Tinggi tanaman}

Tinggi tanaman diukur dari atas permukaan tanah hingga bagian ujung daun 1.1.2. Lilit batang

Pengukuran lilit batang dilakukan dengan cara melilitkan meteran pada batang 1.1.3. Jumlah Daun

Daun yang dihitung merupakan daun yang telah membuka sempurna.

\subsubsection{Luas Daun}

\section{HASIL DAN PEMBAHASAN}

Berdasarkan hasil analisis statistik, pemberian air kelapa tidak berpengaruh terhadap pertambahan tinggi tanaman kelapa pada pada 2 MSP - 10 MSP. Terdapat kecenderungan bahwa perlakuan berupa $50 \%$ air kelapa $+50 \%$ air memberikan pengaruh yang baik dengan kelompok (RAK) dengan tiga kombinasi perlakuan yang diulang enam kali. Percobaan perlakuan meliputi : $\mathrm{A}=100 \%$ air kelapa, $\mathrm{B}=50 \%$ air kelapa $+50 \%$ air, $\mathrm{C}$ $=100 \%$ air.

digunakan adalah emerat, cangkul, penggaris, rafia, alat tulis, dan alat dokumentasi.

setelah perlakuan). Variabel yang diamati selama percobaan berlangsung berupa tinggi tanaman, lilit batang, dan jumlah daun. Pengamatan lainnya berupa luas daun hanya dilakukan pada 0 MSP dan 12 MSP. Pemeliharaan yang dilakukan selama percobaan berlangsung berupa pembumbunan, penyiangan yang dilakukan bersamaan dengan kegiatan pengamatan.

tertinggi (daun ditegakkan) dengan menggunakan meteran.

tanaman kelapa pada ketinggian sekitar 2 $\mathrm{cm}$ dari permukaan tanah dan mengukurnya.

Pengukuran luas daun (LD) dapat diperoleh dengan mengukur panjang dan lebar daun. Luas daun dihitung menggunakan rumus : $\mathrm{LD}=0,59 \mathrm{x}$ panjang $\mathrm{x}$ lebar.

adanya pertambahan tinggi tanaman yang semakin meningkat dibandingkan perlakuan $100 \%$ air dan air saja (Gambar 1). Pertumbuhan tanaman kelapa pada 2 MSP - 6 MSP dengan perlakuan air kelapa 100\% terlihat lebih rendah dibandingkan perlakuan dengan air saja, peningkatan mulai terlihat mulai 6 MST atau 1,5 bulan kemudian. 
Ketersediaan hara $\mathrm{N}$ dan $\mathrm{P}$ pada tanaman yang diberi kombinasi 50\% air kelapa + $50 \%$ air tersebut optimal dan mudah untuk diserap oleh akar sehingga berpengaruh terhadap tinggi tanaman kelapa. Ini disebabkan karena pada air kelapa terdapat cadangan auksin dan sitokinin yg lebih baik. Kandungan auksin dan sitokinin yang terdapat dalam air kelapa mempunyai peranan penting dalam proses pembelahan sel sehingga membantu pembentukan tunas dan pemanjangan batang. Auksin akan memacu sel untuk membelah secara cepat dan berkembang menjadi tunas dan batang (Pamungkas dkk, 2009).

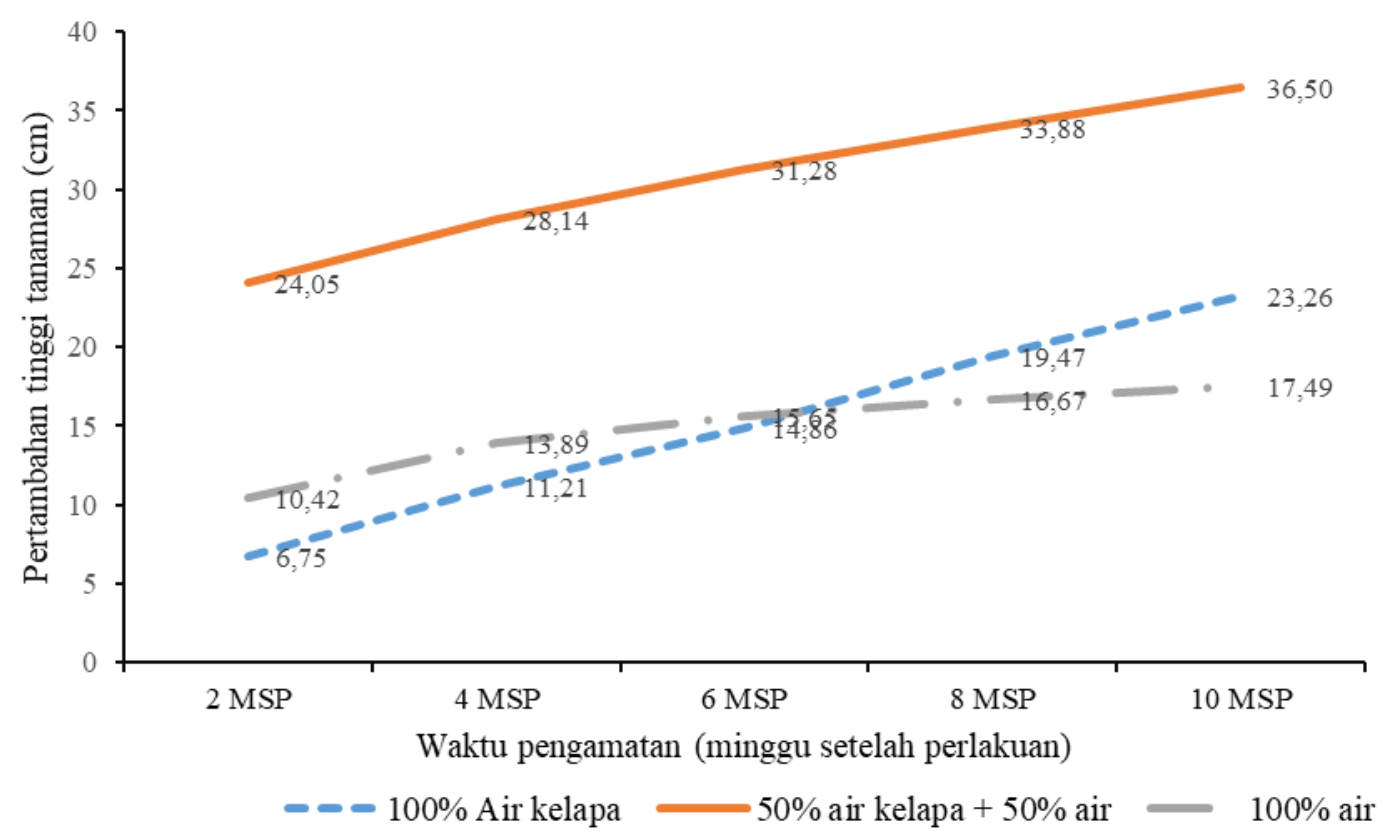

Gambar 1. Grafik pertambahan tinggi tanaman kelapa dengan pemberian air kelapa pada 2 MSP - 10 MSP.

Pemberian air kelapa dengan konsentrasi $50 \%$ mampu meningkatkan pertumbuhan tanaman kelapa setinggi 36.5 $\mathrm{cm}$, sedangkan pemberian air kelapa dengan konsentrasi $100 \%$ dan hanya diberi air saja pertumbuhan tanaman kelapa yang dihasilkan hanya setinggi $23.26 \mathrm{~cm}$ dan $17.49 \mathrm{~cm} \mathrm{~cm}$ selama kurun waktu kurang lebih 2.5 bulan (Gambar 1). Hasil ini sesuai dengan penelitian yang dilakukan Amsyahputra dkk (2016) bahwa pemberian air kelapa dengan konsentrasi 50\% mampu

Berdasarkan data pengamatan tahun 2016, pertambahan tinggi tanaman kelapa yang diamati adalah sebesar $9.03 \mathrm{~cm}$ bulan sedangkan dengan diberikannya perlakuan meningkatkan pertambahan tinggi tanaman kopi. Air kelapa mengandung hormon pertumbuhan seperti auksin, sitokinin dan giberelin (Prades et al., 2012). Auksin dan giberelin yang terkandung dalam air kelapa akan menginisiasi pertumbuhan apikal dan pembesaran sel pada titik tumbuh jaringan meristem batang. Kandungan kalium dalam air kelapa dapat memperlancar masuknya unsur hara atau hormon dengan cara mengatur proses membuka dan menutupnya stomata pada daun (Mukarlina, dkk. 2010). air kelapa berbagai taraf pada tahun 2017, pertambahan tinggi tanaman dengan perlakuan air kelapa 50\%, 100\% dan air saja berturut-turut sebesar $14.6 \mathrm{~cm}$ 
cm/bulan, $9.3 \mathrm{~cm} / \mathrm{bulan}$ dan $7 \mathrm{~cm} / \mathrm{bulan}$. Hal ini menunjukkan pula bahwa penambahan $50 \%$ air kelapa pada air yang

Sitokinin merangsang pembelahan sel melalui peningkatan laju sintesis protein, sedangkan auksin akan memacu pemanjangan sel-sel, sehingga menyebabkan pemanjangan batang (Lakitan, 1996). Mekanisme kerja auksin dalam mempengaruhi pemanjangan sel-sel tanaman yaitu auksin memacu protein tertentu yang ada di membran plasma sel tumbuhan untuk memompa ion $\mathrm{H}^{+}$ke

Pertumbuhan meninggi tanaman idealnya diiringi dengan pertumbuhan lilit batang yang cukup untuk mendukung pertumbuhan tanaman yang proporsional. Keadaan proporsional antara pertumbuhan meninggi dan melebarnya batang tanaman dalam hal pertumbuhan batang sebagai salah satu organ yang berperan dalam menopang kemampuan tegak dan menancap kuatnya tanaman pada media tanam. Pertumbuhan batang yang baik akan menyebabkan tanaman tidak mudah roboh seiring dengan meningginya tanaman. Batang tanaman yang memiliki lilit yang

Berdasarkan hasil analisis statistik, pemberian air kelapa tidak berpengaruh terhadap pertambahan lilit batang tanaman kelapa pada pada 2 MSP - 10 MSP. Pertambahan lilit batang pada tanaman kelapa yang diberi air kelapa dengan konsentrasi $100 \%$ cenderung menunjukkan pengaruh baik (Gambar 2). Hal ini disebabkan semakin pekatnya konsentrasi suatu larutan dalam hal ini larutan air diberikan pada tanaman kelapa membantu meningkatkan pertumbuhan meninggi tanaman sebesar $61.6 \%$.

dinding sel. Ion $\mathrm{H}^{+}$ini mengaktifkan enzim tertentu, sehingga memutuskan beberapa ikatan silang hidrogen rantai molekul selulosa penyusun dinding sel. Sel tumbuhan, kemudian memanjang akibat air yang masuk secara osmosis. Setelah pemanjangan, sel terus tumbuh dengan mensintesis kembali material dinding sel dan sitoplasma (Irwanto, 2003).

menjadi faktor penting dalam keberlangsungan hidup tanaman, dalam hal ini berkaitan dengan tidak mudah robohnya tanaman ketika angin bertiup kencang. Pertambahan lilit batang menggambarkan pertumbuhan tanaman

besar dapat dikatakan memiliki cadangan makanan yang besar, karena tempat penyimpanan cadangan makanan pada TBM terkonsentrasi pada batang. Pertumbuhan batang dengan pertambahan lilit batang yang baik akan membuat tanaman menjadi lebih kuat dan kokoh.

kelapa maka kandungan unsurnya cenderung lebih tinggi. Pertumbuhan lilit batang memerlukan suplai unsur lebih tinggi dibandingkan dengan pertumbuhan tinggi tanaman. Hal tersebut berkaitan dengan pertumbuhan lilit batang yang lebih lambat dibandingkan pertumbuhan tinggi tanaman. Hasil penelitian Oksana dkk. (2012) menyatakan bahwa pertumbuhan sel pada tanaman dirangsang oleh sitokinin, 
selanjutnya sel-sel yang membelah tersebut akan membesar membentuk jaringan yang

Secara genetik perbandingan antara kecepatan pertumbuhan tinggi tanaman (1.749 cm/minggu) dan lilit batang (0.246/minggu) adalah sebesar $7: 1$ yang berarti bahwa setiap tanaman meninggi 7 $\mathrm{cm}$ diiringi dengan pertumbuhan lilit batang

Berdasarkan hasil analisis statistik, pemberian air kelapa tidak berpengaruh terhadap pertambahan jumlah pelepah kelapa pada pada 2 MSP - 10 MSP. Pertumbuhan jumlah pelepah tampaknya lebih dipengaruhi oleh genetik tanaman yang secara umum tanaman kelapa menumbuhkan 1 daun setiap bulan sekali. Gambar.3 menunjukkan bahwa selama periode pengamatan yaitu 10 minggu atau 2,5 bulan tanaman kelapa hanya Gambar 3 menunjukkan bahwa pertumbuhan pelepah sampai dengan 8 MSP atau dua bulan setelah perlakuan menghasilkan respons baik dengan pemberian $100 \%$ air kelapa pada tanaman kelapa. Pada 8 MSP - 10 MSP tanaman yang diberi perlakuan $50 \%$ air kelapa +50 $\%$ air menunjukkan trend peningkatan pertumbuhan pelepah yang lebih baik dibandingkan perlakuan lainnya. Hal ini sejalan dengan penelitian Sujarwati dkk., (2010) yang menyatakan bahwa besar.

sebesar $1 \mathrm{~cm}$. Perhitungan ini berdasarkan data pada perlakuan dengan air saja yang dapat dianggap sebagai besaran air yang ditambahkan dalam kegiatan penyiraman atau berasal dari air hujan.

menumbuhkan 1 pelepah saja.Pertambahan jumlah pelepah daun optimal pada TBM yaitu 1 helai daun perbulan (Mardiatmoko dan Ariyanti, 2018). Tanaman ini mengalami pertumbuhan pelepah yang lebih lambat dari keadaan genetiknya, dapat disebabkan kandungan air tanah yang tidak cukup tersedia bagi tanaman sehingga berpengaruh terhadap pertumbuhan pelepah yang terjadi.

pertumbuhan bibit palem putri mulai meningkat pada penggunaan air kelapa dengan konsentrasi 50\%. Pelepah daun tanaman merupakan faktor pertumbuhan vegetatif yang berpengaruh terhadap proses fotosintesis dalam menghasilkan fotosintat tanaman. Pertumbuhan daun pada tanaman kelapa dapat menunjang pertumbuhan bunga pada fase generatif. Setiap 2 daun akan menunjang pertumbuhan satu mayang (bunga) pada tanaman kelapa (Mardiatmoko dan Ariyanti, 2018). 


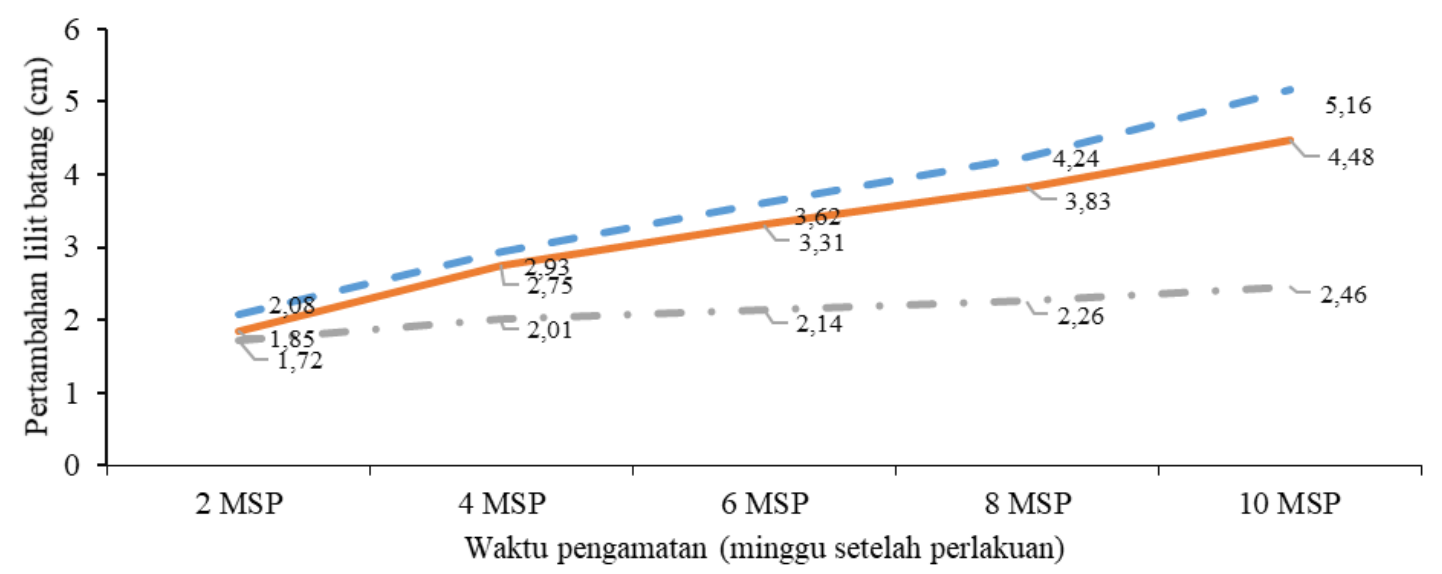

$-\quad-100 \%$ Air kelapa $\quad-50 \%$ air kelapa $+50 \%$ air $\quad-\quad 100 \%$ air

Gambar 2. Grafik pertambahan lilit batang tanaman kelapa dengan pemberian air kelapa pada 2 MSP - 10 MSP.

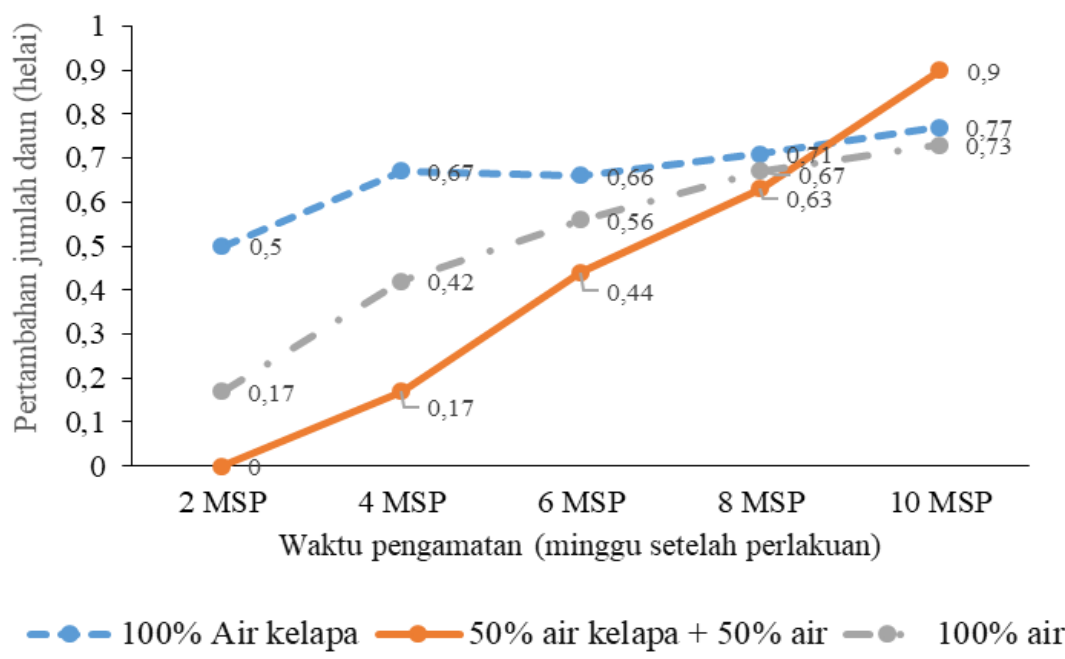

Gambar 3. Grafik pertambahan jumlah pelepah tanaman kelapa dengan pemberian air kelapa pada 2 MSP - 10 MSP.

Pertumbuhan pelepah berkaitan dengan pertumbuhan meninggi dan ukuran batang meskipun dalam hal ini tidak dihitung nilai korelasinya. Perlakuan pemberian air saja menghasilkan pertumbuhan pelepah dengan trend peningkatan yang lebih rendah dibandingkan dengan perlakuan dengan air kelapa pada 8 MSP - 10 MSP. Trend ini terjadi pula pada pertumbuhan meninggi tanaman dan lilit batang. Air kelapa dapat dijadikan stimulus pertumbuhan tanaman kelapa dengan terkandungnya hormon pertumbuhan diantaranya auksin dan sitokinin. Menurut Yong et al. (2009), air kelapa mengandung berbagai macam zat, termasuk di dalamnya sitokinin, auksin, giberelin dan asam absisat (ABA). Air 
kelapa mengandung komposisi kimia yang unik yang terdiri dari mineral, vitamin, gula, asam amino, dan fitohormon yang Pertumbuhan tanaman secara keseluruhan tidak terlepas dari peranan daun sebagai organ fotosintesis yang menyelenggarakan proses fotosintes dalam menghasilkan fotosintat. Karakter daun diantaranya dapat digambarkan dengan jumlah daun dan luas daun. Menurut Wulandari dkk. (2013), jumlah dan ukuran daun dipengaruhi oleh genotip dan lingkungan. Lingkungan yang relatif tetap

Berdasarkan hasil analisis statistik pemberian air kelapa pada tanaman kelapa menghasilkan perbedaan yang nyata terhadap luas daun (Tabel 4). Pemberian $100 \%$ air kelapa menghasilkan daun terlebar dibandingkan perlakuan 50\% air memiliki efek signifikan terhadap pertumbuhan tanaman (Winarto, 2015).

kondisinya memungkinkan primordial daun tumbuh pada ujung batang dengan kecepatan pertumbuhan yang konstan. Luas daun menjadi faktor penting karena berkaitan dengan luas permukaan daun yang dapat menangkap sinar matahari untuk bahan baku fotosintesis. Semakin luas daun semakin banyak energi matahari yang dapat ditangkap.

kelapa dan dengan air saja. Setiawan (2013) menyatakan bahwa luas daun yang besar meningkatkan laju fotosintesis tanaman sehingga akumulasi fotosintat yang dihasilkan menjadi tinggi.

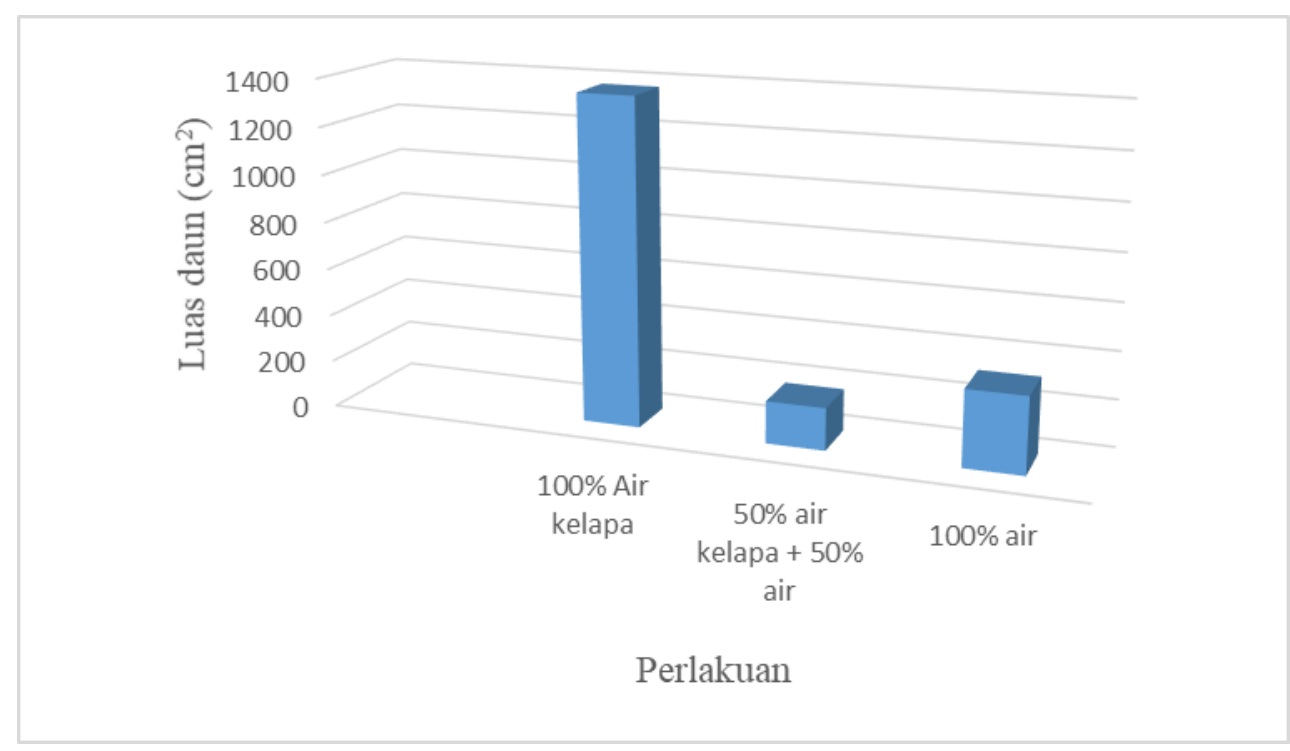

Gambar 4. Diagram pertambahan luas daun tanaman kelapa dengan pemberian air kelapa pada 10 MSP.

Ket: angka-angka yang diikuti huruf yang sama berarti tidak berbeda nyata menurut Uji BNT taraf 5\% 
Air kelapa konsentrasi 100\% mampu menumbuhkan daun lebih lebar sehingga memungkinkan fotosintat yang dihasilkan lebih banyak. Pertumbuhan tanaman secara keseluruhan dapat menjadi lebih baik dengan adanya suplai fotosintat yang optimal. Pemberian air kelapa dengan konsentrasi yang lebih pekat nyatanya

\section{KESIMPULAN}

Pemberian air kelapa sebagai hasil ikutan dari buah kelapa pada tanaman kelapa bermanfaat baik untuk pertumbuhan tanaman kelapa itu sendiri. Pemberian air

\section{SARAN}

Diperlukan analisis lebih lanjut mengenai air kelapa yang digunakan terutama dalam hal kandungan unsur hara sehingga dapat dikaitkan dengan manfaatnya bagi pertumbuhan tanaman kelapa. Percobaan ini perlu dilanjutkan

\section{UCAPAN TERIMA KASIH}

Ucapan terima kasih kepada mahasiswa dan mahasiswi minat perkebunan angkatan 2014, Departemen Budidaya Pertanian, Fakultas Pertanian,

\section{DAFTAR PUSTAKA}

Dirjenbun. 2012. Peningkatan Produksi, Produktivitas dan Mutu Tanaman Tahunan. Available at http://ditjenbun.pertanian.go.id/tinymc puk/gambar/file/Pedoman Teknis Pengembangan Tanaman Kelapa. pdf. Diakses 5 Mei 2018. mampu merangsang pertumbuhan ukuran daun yang lebih besar. Menurut Permana (2019), pemberian 100\% air kelapa yang dikombinasikan dengan $20 \mathrm{ml}$ asam humat menberikan respons terbaik pada pertambahan ukuran lilit batang tanaman kelapa kopyor pada 8 MSP - 24 MSP.

kelapa dengan konsentrasi 100\% menghasilkan respons terbaik pada pertumbuhan luas daun kelapa pada fase TBM. Air kelapa dengan konsentrasi 50\% cenderung menghasilkan peningkatan pertumbuhan tinggi kelapa TBM.

untuk mengetahui pengaruh air kelapa yang dikombinasikan dengan teknik budidaya lainnya misalnya perlakuan ZPT sintetik, pupuk organik, pemangkasan. Aplikasi air kelapa sebagai ZPT alami dapat dicobakan pada komoditi tanaman perkebunan lainnya selain kelapa.

Universitas Padjadjaran yang telah membantu dalam pelaksanaan penelitian ini.

Dewan Kelapa Indonesia. 2014. Bermusyawarah dan Berkoordinasi bagi Pembangunan Perkelapaan Nasional tahun 2019. Notulensi rapat Dewan Kelapa Indonesia. Diakses dari www.dekindo.com/acara/rapat. pada tanggal 28 Desember 2017.

Saptaji, Setyono, and Rochman, N. 2015. Pengaruh Air Kelapa dan Media Tanam 
terhadap Pertumbuhan Stek Stevia (Stevia rebaudiana Bertoni), Jurnal Agronida Volume 1 No 2, hal 83-91.

Tiwery, Riny, R. 2014. Pengaruh Penggunaan Air Kelapa terhadap Pertumbuhan Tanaman Sawi. Biopendix Volume 1 No 1, hal 83-91.

Yong, J.W.H., Ge, L., Ng, Y.F., and Tan, S.N. 2009. The Chemical Composition and Biological Properties of Coconut (Cocos nucifera L.) Water, Molecules Volume 14 No 12, hal 5144-5164.

Rosniawaty, S., Anjarsari, I.R.D., dan Sudirja, R. 2018. Aplikasi sitokinin untuk meningkatkan pertumbuhan tanaman teh di dataran rendah, $J$. Tanaman Penyegar dan Industri Volume 5 No.1, hal 36-37.

Torar, Daniel, J. 2010. Adopsi Teknologi dan Analisis Finansial pada Pengolahan Minuman Ringan dan Sirup Air Kelapa di Kabupaten Minahasa. Manado: Balai Penelitian Tanaman Kelapa dan Palma Lain. Hal 18.

Fodhil, M. 2014. Pengaruh Konsentrasi Air Kelapa pada Pembibitan Tanaman Buah Naga (Hylocereus costaricencis), Jurnal Online Mahasiswa Volume 1 No 1. https://jom.unri.ac.id/index.php/JOMF APERTA/article/view/2659/2591. Diakses 15 Mei 2018

Renvillia, R., Bintoro, A., and Riniarti, M. 2016. Penggunaan Air Kelapa untuk Stek Batang Jati (Tectona grandis), Jurnal Sylva Lestari Volume 4 No 1, hal $61-68$.

Fahmi, Z.I. 2016. Kajian Pengaruh Sitokinin terhadap Pertumbuhan Tanaman. Balai Besar Perbenihan dan Proteksi Tanaman Surabaya. https://www.academia.edu. Diakses 10 Mei 2018.
Panut, D. 2008. Panduan Lengkap Pestisida dan Aplikasinya. AgroMedia, Jagakarsa.

Pamungkas, F. T., Darmanti, S., dan Raharjo, B. 2009. Pengaruh

Konsentrasi dan Lama Perendaman dalam Supernatan Kultur Bacillus sp. terhadap Pertumbuhan Stek Horizontal Batang Jarak Pagar (Jatropha curcas L.), Jurnal Sains \& Matematika, Volume 17 No 3, hal 131-140. https://ejournal.undip.ac.id/index.php/s $\mathrm{m} /$ article/view/3277. Diakses 16 Mei 2018.

Amsyahputra, A. 2016. Pemberian Berbagai Konsentrasi Air Kelapa pada Bibit Kopi Robusta (Coffea canephora Pierre). Jurnal Online Mahasiswa 3(2) :1-12. Universitas Riau. https://jom.unri.ac.id/index.php/JOMF APERTA/article/view/11463. Diakses 15 Mei 2018.

Prades, A., Dornier, M., Diop, N. dan Pain, P. 2012. Coconut water uses, composition and properties: a review. Journal of fruits Volume 67 No 2, hal 87-107.

Mukarlina, A., Listiawati, dan Mulyani, S. 2010. The Effect of Coconut Water and Naphthalene Acetic Acid (NAA) Application on the in Vitro Growth of Paraphalaeonopsis serpentilingua from West Kalimantan, Nusantara Bioscience Volume 2 No 2, hal 62-66.

Lakitan, B. 1996. Fisiologi Pertumbuhan dan Perkembangan Tanaman. PT Raja Grafindo Persada. Jakarta.

Irwanto. 2003. Biologi. Alih Bahasa Wasmen Manalu.Erlangga. Jakarta.

Oksana, Rahmadani, E., dan Syamsul. 2012. Peranan Berbagai Macam Media Tumbuh bagi Pertumbuhan Stek Daun Jeruk J.C (Japanche citroen) dengan Beberapa Konsentrasi BAP, Jurnal 
Agroteknologi Volume 2 No 2. Hal 47.

Mardiatmoko, G., dan Ariyanti, M. 2018. Produksi Tanaman Kelapa (Cocos nucifera. L). Buku panduan. Badan Penerbit Fakultas Pertanian Universitas Pattimura. Ambon.

Sujarwati, S. F., Fathonah, S., Johani, E dan Herlina. 2010. Penggunaan Air

Wulandari, R.C., Linda, R., dan Mukarlina. 2013. Pertumbuhan Setek Melati Putih (Jasminum sambac (L.) W. Ait.)

Setiawan, P. 2013. Pengaruh Perendaman Benih Kakao dalam Air Kelapa dan Pemberian Pupuk NPKMg (15-15-6-4) terhadap Pertumbuhan Bibit Kakao (Theobroma cacao L.), Jurnal Online Agroteknologi Volume 1 Nomor 4, hal 37-40.
Kelapa untuk Meningkatkan Perkecambahan dan Pertumbuhan Palem Putri (Veitchia merilli), Jurnal Sagu Volume 10 No. 1, Hal 24-29.

Winarto, B. 2015. Use of Coconut Water and Fertilizer for in Vitro Proliferation and Plantlet Production of Dendrobium ' Gradita 3'. in Vitro Cell Development, Biology Journal Volume 51, hal $303-314$.

dengan Pemberian Air Kelapa dan IBA (Indole Butyric Acid), J. Protobiont Volume 2 No 2, hal 39-43.

Permana, M.R. 2019. Respons Pertumbuhan Tanaman Kelapa Kopyor (Cocos nucifera L.) Belum Menghasilkan terhadap Kombinasi Aplikasi Air Kelapa dan Asam Humat. Skripsi. Fakultas Pertanian. Universitas Padjadjaran. 
